Journal of Organometallic Chemistry, 234 (1982) 137-141

Elsevier Sequoia S.A., Lausanne - Printed in The Netherlands

\title{
PREPARATION OF HALOMETIIANEBORONATES
}

PETER G.M. WUTS * and PAUL A. THOMPSON

Department of Chemistry, The University of Michigan, Ann Arbor, Michigan 48109 (U.S.A.)

(Received December 24th, 1981; in revised form March 9th, 1982)

\section{Summary}

A facile preparation of iodomethaneboronic esters is described. The key step utilizes a tin hydride reduction of dichloromethaneboronic esters.

The facility with which $\alpha$-haloboron compounds undergo substitution with a variety of nucleophiles augurs favorably for their use as potential intermediates in a wide variety of useful synthetic transformations. For example, they have been used to alkylate en:umines [1], enolates [2], malonates [1], lithium amides $[6]$, mercaptans $[1,2,5]$, alkyllithiums and Grignard reagents $[2,3,4,9]$. As an approach to the synthesis of a variety of $\boldsymbol{\gamma}$-substituted allylboronates [7], we required a simple and direct source of iodomethaneboronates. Matteson has reported two procedures for iodomethaneboronate preparation but these are encumbered with a number of disadvantages especially when large quantities of material are required $[1,8]$.

We now wish to report a facile and direct synthesis of iodo- and chloromethaneboronates from readily available starting materials. Our approach takes advantage of Rathke's procedure for the preparation of diisopropyl dichloromethaneboronate (I) [9]. Reduction of the dichloride should then provide a useful entry into the chloromethaneboronate esters. Rathke had previously attempted the reduction with sodium hydride in a variety of solvents but found the dichloride inert to sodium hydride. The general ability of tributyltin hydride to selectively reduce geminal dihalides to monohalides [10] led us to believe that the dichloride I should also undergo selective reduction. Indeed, stirring an equimolar amount of tributyltin hydride and dichloride $I$ in benzene with a catalytic amount of AIBN gave after $24 \mathrm{~h}$ quantitative conversion to chloromethaneboronate (II). Distillation to remove tributyltin chloride afforded pure monochloride II in quantitative yield. Transesterification with 2,2-dimethylpropane-1,3-diol afforded chloride III in 92\% yield. Finkelstein reaction on the chloride provides an $81 \%$ yield of iodide (IV). Alternatively, diisopropyl dichloromethaneboronate (I) could first be transesterified to 
$\left(i-\mathrm{PrO}_{2} \mathrm{BCHCl}_{2}\right.$ (I)
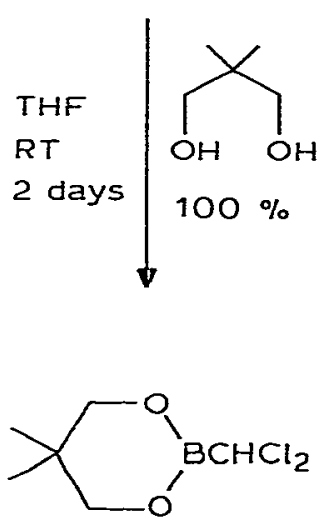

(V)
$\mathrm{Bu}_{3} \mathrm{SnH}$

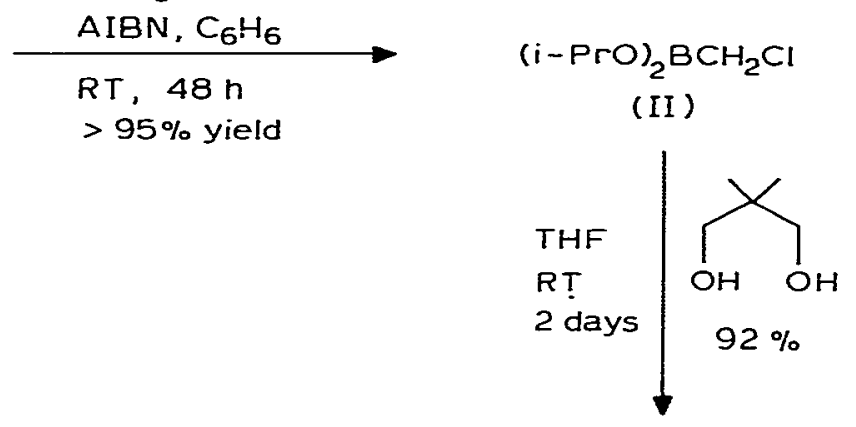

$\mathrm{Bu}_{3} \mathrm{SnH}$
$\underset{\text { AIBN, } \mathrm{C}_{6} \mathrm{H}_{6}}{\mathrm{RT}, 48 \mathrm{n}}$
$100 \%$ yield

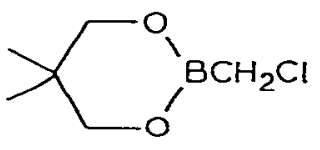

(III)
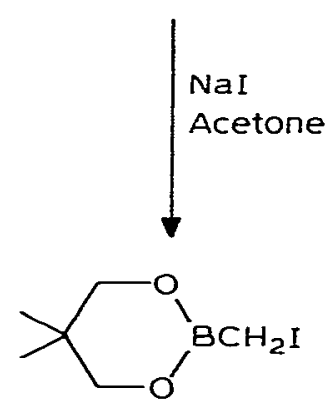

(IV)
$\mathrm{Cl}_{2} \mathrm{CHB}(\mathrm{OH})_{2}$

(VI) $\underset{89 \%}{\text { Pinacol } \cdot 6 \mathrm{H}_{2} \mathrm{O}}$

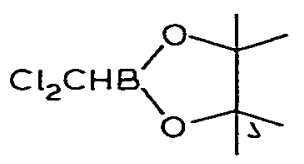

(VII)

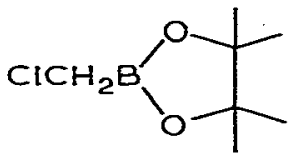

(VIII)

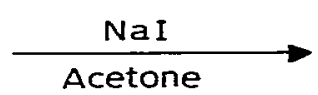

Acetone

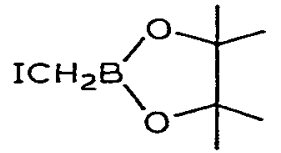

(IX) 
ester V and then reduced to chloride III. A similar set of transformations was used to prepare the pinacolyl ester IX with equal efficiency except that the pinacolyl ester VII was prepared directly in $89 \%$ yield from boronic acid VI. Reduction to the monochloride VIII and iodide substitution gave ester IX. For most purposes, it should not be necessary to carry out the final Finkelstein reaction since the chloride should behave like the iodide except that its reactivity may be somewhat reduced.

In conclusion we have developed a simple and straightforward procedure for the preparation of monohalomethaneboronates on a molar scale. The now ready availability of these reagents should expand the scope of their use in a variety of transformations.

\section{Experimental}

Tetrahydrofuran and diethyl ether were distilled from $\mathrm{Na}$ and benzophenone under an argon atmosphere. Benzene was distilled from $\mathrm{CaH}_{2}$ under an argon atmosphere. Acetone was stirred over anhydrous $\mathrm{K}_{2} \mathrm{CO}_{3}$, anhydrous, and freshly distilled prior to use. Solutions of t-butyllithium (1.9 $M$ in pentane) were obtained from Alfa or Aldrich Chemical Co. All reactions were carried out under an atmosphere of argon in a flamedried apparatus. Proton NMR spectra were taken on a Varian T-60A or Brüker $360 \mathrm{MHz}$ spectrometer using TMS as an internal standard. Carbon-13 NMR were obtained using a JEOL FX-90Q spectrometer, using TMS of $\mathrm{CDCl}_{3}$ as internal standard. Elemental analyses were performed by Spang Microanalytical Laboratories, Eagle Harbor, Michigan. Infrared spectra were obtained on a Beckman IR 4240 or Perkin-Elmer 727B spectrometer using $\mathrm{NaCl}$ windows. Boiling points are uncorrected.

\section{Preparation of diisopropyl chloromethaneboronate (II)}

Tri-n-butyltin hydride $(3.93 \mathrm{~g}, 13.5 \mathrm{mmol})$ was added to diisopropyl dichloromethaneboronate $(2.88 \mathrm{~g}, 13.5 \mathrm{mmol})$ dissolved in $20 \mathrm{ml}$ of dry benzene. A catalytic amount $(20 \mathrm{mg})$ of $2,2^{\prime}$-azobis-(2-methylpropionitrile) was introduced and the resulting solution stirred for $24 \mathrm{~h}$ at room temperature. Fractional distillation gave $2.4 \mathrm{~g}$ (quantitative yield) of the $\alpha$-chloromethaneboronate as a colorless liquid, b.p. $53-56^{\circ} \mathrm{C} / 0.8 \mathrm{mmHg}$, proton $\mathrm{NMR}\left(\mathrm{CDCl}_{3}\right)$ : septet, $\delta 4.40(2 \mathrm{H})$; singlet, $\delta 2.84(1 \mathrm{H})$; doublet, $\delta 1.2(12 \mathrm{H})$. IR (neat): 7.13 , $7.25,7.54,8.36,8.52,8.91,10.55,13.58 \mu .{ }^{13} \mathrm{C}$ NMR $\left(\mathrm{CDCl}_{3}\right): 66.30 \mathrm{ppm}(\mathrm{d})$; $24.53 \mathrm{ppm}(\mathrm{q})$, (downfield from TMS). Found: $\mathrm{C}, 47.20 ; \mathrm{H}, 8.95 ; \mathrm{Cl}, 19.94$; $\mathrm{C}_{7} \mathrm{H}_{16} \mathrm{O}_{2} \mathrm{BCl}$ calcd.: $\mathrm{C}, 47.11 ; \mathrm{H}, 9.04 ; \mathrm{Cl}, 19.86 \%$.

Preparation of 5,5-dime ihyl-2-chloromethyl-2-bora-1,3-dioxacyclohexane (III) from diisopropyl ester (IV)

2,2-Dimethyl-1,3-propanediol $(0.44 \mathrm{~g}, 4.2 \mathrm{mmol})$ was added to diisopropyl chloromethaneboronate $(0.75 \mathrm{~g}, 4.2 \mathrm{mmol})$ dissolved in $25 \mathrm{ml}$ of dry THF. The solution was stirred for 3 days at room temperature. Fractional distillation gave $0.63 \mathrm{~g} \mathrm{(92 \% )}$ of the chloromethaneboronate as a colorless liquid, b.p. $82-87^{\circ} \mathrm{C} /$ $5 \mathrm{mmHg}$, identical with the product obtained by the alternative route. 
Preparation of 5,5-dimethyl-2-chloromethyl-2-bora-1,3-dioxacyclohexane (III) from ester $(V)$

Tri-n-butyltin hydride $(21.64 \mathrm{~g}, 74.7 \mathrm{mmol})$ was added to 5,5-dimethyl-2dichloromethane-2-bora-1,3-dioxacyclchexane $(14.64 \mathrm{~g}, 74.7 \mathrm{mmol})$ dissolved in $250 \mathrm{ml}$ of dry benzene. A catalytic amount $(100 \mathrm{mg})$ of $2,2^{\prime}$-azobis(2-methylpropionitrile) was introduced and the resulting solution stirred for $24 \mathrm{~h}$ at room temperature. Fractional distillation gave $11.8 \mathrm{~g} \mathrm{(98 \% )}$ of the chloromethaneboronate III as a colorless liquid, b.p. $89-90^{\circ} \mathrm{C} / 10 \mathrm{mmHg}$, proton NMR $\left(\mathrm{CDCl}_{3}\right)$ : singlet, $\delta 3.62(4 \mathrm{H})$; singlet, $\delta 2.85(2 \mathrm{H})$; singlet, $\delta 0.97$ $(6 \mathrm{H}) .{ }^{13} \mathrm{C} \mathrm{NMR}\left(\mathrm{CDCl}_{3}\right): 71.96 \mathrm{ppm}(\mathrm{t}) ; 21.26 \mathrm{ppm}(\mathrm{q})$. IR (neat): 6.76, 6.98, 7.27, 7.46, 7.62, 7.91, 8.51, 9.32, 9.91, 12.27 $\mu$. Found: $\mathrm{C}, 44.51 ; \mathrm{H}, 7.57$; Cl, 21.05. $\mathrm{C}_{6} \mathrm{H}_{12} \mathrm{O}_{2} \mathrm{BCl}$ calcd.: $\mathrm{C}, 44.37 ; \mathrm{H}, 7.45 ; \mathrm{Cl}, 21.18 \%$.

Preparation of 5,5-dimethyl-2-iodomethyl-2-bora-1,3-dioxacyclohexane (IV)

Sodium iodide $(16.2 \mathrm{~g}, 108.2 \mathrm{mmol})$ was added to 5,5-dimethyl-2-chloromethyl-2-bora-1,3-dioxacyclohexane $(11.7 \mathrm{~g}, 72.1 \mathrm{mmol})$ dissolved in $150 \mathrm{ml}$ of dry acetone. The mixture was refluxed for $48 \mathrm{~h}$. All volatile materials were distilled (Kugelrohr) to remove insoluble salts. Fractional distillation of the resulting yellow mixture gave $14.9 \mathrm{~g}(81 \%)$ of the iodomethaneboronate IV as a colorless liquid, b.p. $40-43^{\circ} \mathrm{C} / 0.2 \mathrm{mmHg}$, which was stored over $\mathrm{Cu}$ wire. Proton NMR $\left(\mathrm{CDCl}_{3}\right)$ : singlet, $\delta 3.61(4 \mathrm{H})$; singlet, $\delta 2.08(2 \mathrm{H})$; singlet, $\delta 0.99$ (6H). ${ }^{13} \mathrm{C}$ NMR $\left(\mathrm{CDCl}_{3}\right): 71.92 \mathrm{ppm}(\mathrm{t}) ; 21.43 \mathrm{ppm}(\mathrm{q})$. IR (neat): 6.78, 7.01, $7.13,7.61,7.80,7.94,9.00,9.93,12.28 \mu$. Found: C, $28.44 ; \mathrm{H}, 4.68 ; \mathrm{I}, 49.90$. $\mathrm{C}_{6} \mathrm{H}_{12} \mathrm{O}_{2} \mathrm{BI}$ calcd.: $\mathrm{C}, 28.39 ; \mathrm{H}, 4.76 ; \mathrm{I}, 49.99 \%$.

Preparation of 5,5-dimethyl-2-dichloromethyl-2-bora-1,3-dioxacyclohexane (V)

2,2-Dimethyl-1,3-propanediol ( $41.08 \mathrm{~g}, 0.395 \mathrm{~mol})$ was added to diisopropyl dichloromethaneboronate $(84 \mathrm{~g}, 0.395 \mathrm{~mol})$ dissolved in $500 \mathrm{ml}$ of dry tetrahydrofuran. Stirring for 3 days at room temperature followed by fractional distillation gave $74.6 \mathrm{~g}(96 \%)$ of the 2,2-dimethyl-1,3-propanediol ester as a colorless liquid, b.p. $89-91^{\circ} \mathrm{C} / 5 \mathrm{mmHg}$, proton $\mathrm{NMR}\left(\mathrm{CDCl}_{3}\right)$ : singlet, $\delta 5.19$ (1H); singlet, $\delta 3.71(4 \mathrm{H})$; singlet, $\delta 1.02(6 \mathrm{H})$. IR (neat): 6.62, 6.71, 6.92, $7.22,7.43,7.60,7.84,8.61,9.27,9.84,13.62 \mu$. Found: $\mathrm{C}, 36.72 ; \mathrm{H}, 5.71 ; \mathrm{Cl}$, 35.95. $\mathrm{C}_{6} \mathrm{H}_{11} \mathrm{O}_{2} \mathrm{BCl}_{2}$ calcd.: $\mathrm{C}, 36.60 ; \mathrm{H}, 5.63 ; \mathrm{Cl}, 36.02 \%$.

Preparation of 4,4,5,5-tetramethyl-2-dichloromethyl-2-bora-1,3-cyclopentane (VII) from dichloromethane

By use of $63.7 \mathrm{~g}(0.75 \mathrm{~mol})$ of dichloromethane, $437.5 \mathrm{ml}(0.7 \mathrm{~mol}$ of $\mathrm{n}$-butyllithium (1.6 $\mathrm{M}$ in hexane), and $78.7 \mathrm{~g}(0.75 \mathrm{~mol})$ of trimethylborate, the dichloromethaneboronic acid was prepared by Rathke's method. The crude material obtained following workup and solvent removal (in vacuo) was taken up in $1500 \mathrm{ml}$ of benzene along with $170 \mathrm{~g}(0.75 \mathrm{~mol})$ of pinacol $\cdot 6 \mathrm{H}_{2} \mathrm{O}$. The biphasic mixture was then heated to reflux under an argon atmosphere, utilizing a Dean-Spark trap to remove water as an azeotrope. After $72 \mathrm{~h}$ at reflux, the homogeneous yellow solution was cooled to room temperature and then fractionally distilled (all under inert atmosphere) to yield $140.6 \mathrm{~g}(89 \%)$ of the desired dichloromethaneboronate, b.p. $103^{\circ} \mathrm{C} / 20 \mathrm{mmHg}$. NMR $\left(\mathrm{CDCl}_{3}\right)$ : singlet, $\delta 5.36(1 \mathrm{H})$; singlet, $\delta 1.36(12 \mathrm{H})$. IR (neat): $3.36,3.41,6.77,6.82,7.11$, 
$7.25,7.33,7.38,7.87,8.25,8.58,8.79,9.01,10.32,11.13,11.82,13.55$, $15.47 \mu$. Found: $\mathrm{C}, 39.93 ; \mathrm{H}, 6.24 ; \mathrm{Cl}, 33.67 . \mathrm{C}_{7} \mathrm{H}_{13} \mathrm{O}_{2} \mathrm{BCl}_{2}$ calcd.: $\mathrm{C}, 39.87$; $\mathrm{H}, 6.21 ; \mathrm{Cl}, 33.62 \%$.

Preparation of 4,4,5,5-tetramethyl-2-chloromethyl-2-bora-1,3-dioxacyclopentane (VIII)

The procedure for the preparation of ester III from ester V was followed. Distillation gave the monochloride in $90 \%$ yield, b.p. $81^{\circ} \mathrm{C} / 14 \mathrm{mmHg}$. NMR: singlet: $\delta 2.77(2 \mathrm{H})$; singlet, $\delta 1.22(12 \mathrm{H})$. IR (neat): $3.35,3.41,6.78,7.04$, 7.16, 7.21, 7.26, 7.35, 7.80, 8.19, 8.37, 8.50, 8.70, 8.97, 10.25, 11.17, 11.65, $13.60,14.75 \mu$. Found: $\mathrm{C}, 47.44 ; \mathrm{H}, 7.89 ; \mathrm{Cl}, 19.96 . \mathrm{C}_{7} \mathrm{H}_{14} \mathrm{O}_{2} \mathrm{BCl}$ calcd.: $\mathrm{C}$, $47.65 ; \mathrm{H}, 8.00 ; \mathrm{Cl}, 20.09 \%$.

Preparation of 4,4,5,5-tetramethyl-2-iodomethyl-2-bora-1,3-dioxacyclopentane (IX) from ester (VIII)

The procedure for the preparation of iodide IV was followed. Distillation gave iodide IX in quantitative yield, by $71^{\circ} \mathrm{C} / 15 \mathrm{mmHg}$. NMR: singlet, $\delta 2.12$ $(2 \mathrm{H})$; singlet, $\delta 1.23(12 \mathrm{H})$. IR (neat): $3.38,3.40,3.46,6.75,7.01,7.12,7.28$, $7.59,7.76,7.94,8.25,9.05,9.38,9.92,10.25,12.30 \mu$. Found: C, 31.47; H, $5.32 ; \mathrm{I}, 47.25 . \mathrm{C}_{7} \mathrm{H}_{4} \mathrm{O}_{2} \mathrm{BI}$ calcd.: $\mathrm{C}, 31.3837 ; \mathrm{H}, 5.2674 ; \mathrm{I}, 47.3694 \%$.

\section{Acknowledgement}

The work was supported by the National Science Foundation (Grant \# CHE8019770) and the Petroleum Research Fund administered by the American Chemical Society. We also wish to acknowledge the National Science Foundation for our NMR facilities (Grant \# CHE-79 09108).

\section{References}

1 D.S. Matteson and T.C. Cheng, J. Org. Chem., 33 (1968) 3055.

2 D.S. Matteson and D. Majundar, J. Am. Chem. Soc., 102 (1980) 7590.

3 H.C. Brown and N.R. Delue, J. Org. Chem., 42 (1977) 4088.

4 D.S. Matteson and $K$. Ame. J. Am. Chem. Soc., 100 (1978) 1325.

5 D.S. Matteson and G.D. Schaumberg. J. Org. Chem., 31 (1966) 726.

6 D.S. Matteson. K.M. Sadhu and G.E. Lienhard, J. Am. Chem. Soc., 103 (1981) 5241.

7 P.G.M. Wuts and Paul A. Thompson, in preparation; R.W. Hoffmann and B. Kemper, Tetrahedron Lett.. (1980) 4883 .

8 D.S. Matteson and D. Majundar, J. Organometal. Chem., 170 (1979) 259.

9 M.W. Rathke. E. Chao and G. Wu. J. Organometal. Chem., 122 (1976) 145.

10 H.G. Kuivila. Acc. Chem. Res., 1 (1968) 289. 